\title{
PEMANFAATAN SAMPAH KERTAS SEBAGAI BAHAN BAKU PAPERBOARD UNTUK MEMPRODUKSI BENDA FUNGSI DAN ESTETIK
}

\author{
Firman Hawari, Agus Sachari, Adhi Nugraha \\ (Email: firmanhawari@ymail.com) \\ Program Pascasarjana Seni Rupa dan Desain \\ Fakultas Seni Rupa dan Desain \\ Institut Teknologi Bandung \\ Jl Ganesha 10, Bandung, Indonesia
}

\begin{abstract}
ABSTRAK
Arah pelaksanaan kajian ini adalah mengurangi ketergantungan pada sumber daya alam dan melestarikannya dari kepunahan, terutama sumber daya alam kayu. Muatan green design mendominasi sistematika pelaksanaan dalam setiap tahapan. Ide awal penelitian ini adalah menemukan cara untuk menciptakan alternatif bahan bangunan yang ramah lingkungan. Salah satu implementasinya adalah melakukan eksperimen produksi panel dari bahan sampah kertas. Panel kertas mempunyai kemampuan sama dengan produk panel yang sudah ada sebelumnya. Tujuannya adalah mengaplikasikan panel kertas sebagai bahan perancangan interior sebuah bangunan, baik untuk fungsi konstruksi maupun estetis. Pertimbangan pemilihan bahan panel sebagai objek produksi antara lain ruang lingkup pemanfaatan yang luas, fleksibilitas, easy treatment, serta faktor masyarakat yang sudah terbiasa. Secara bentuk, jenis sampah kertas mempunyai bentuk lembaran yang tipis, lemas, dan rapuh. Karakter ini sangat mendukung pelaksanaan persepsi tersebut. Selanjutnya, karakter ini menjadi stimulus untuk memunculkan metode manufacture, yaitu konfigurasi silang vertikal, dengan memanfaatkan lembaran kertas yang lemas serta rapuh kemudian melalui beberapa tahapan penyusunan sampai menjadi bidang panel dengan ketebalan $20 \mathrm{~mm}$ bersifat keras, kokoh, dan kuat.
\end{abstract}

Kata kunci: elemen perancangan interior; konfigurasi silang vertical; konsep gempal; panel; sampah kertas

\begin{abstract}
The direction of the implementation of this study is to reduce dependence on natural resources and preserve them from extinction, especially timber natural resources. Green design content is a systematic implementation in each stage. An initial idea was to find an alternative building material that was environmentally friendly. One of the implementations is conducting experiments on panel production from paper waste materials. Paper panels that have the same capabilities as pre-existing panel products. The aim is to make it an interior design material for building, both for construction and aesthetic functions. The consideration of the selection of panel materials is the wide scope of utilization, flexibility, easy treatment, and factors of people who are used to it. In full, this type of paper waste contains forms that are fatty, limp and fragile. This character strongly supports the implementation of that perception. Furthermore, this character becomes a stimulus to bring up the manufacturing method, which is a vertical crossconfiguration, which uses limp and fragile sheet paper and then arranged into a panel area with a thickness of $20 \mathrm{~mm}$ which requires hard, sturdy, and strong properties.
\end{abstract}

Keywords: concept of stocky; element of interior design; panel; paper waste; vertical cross configuration 


\section{PENDAHULUAN}

Gagasan pelaksanaan kajian ini berawal dari pengamatan sekilas terhadap melimpahnya jumlah sampah kertas di area kantor, usaha fotokopi dan percetakan, sekolah dan area lainnya. Jumlah yang melimpah dapat berarti adanya ketersediaan supply bahan dasar dan murah. Dari sudut pandang manajemen produksi, hal ini merupakan salah satu faktor peluang industri baru. Dapat dikatakan bahwa keberadaan sampah kertas di area perkotaan bukan sebuah masalah tetapi sebuah peluang yang cukup menjanjikan secara teknologi dan pemanfaatan.

Perlu diketahui, di Indonesia gerakan pengurangan emisi rumah kaca ditindaklanjuti dengan dibuatnya Undang-Undang Industri Hijau oleh Kementerian Perindustrian Republik Indonesia berdasarkan Undang-Undang Republik Indonesia No. 3 tahun 2014 tentang Perindustrian, yakni industri yang dalam proses produksinya mengutamakan upaya efisiensi dan efektivitas penggunaan sumber daya secara berkelanjutan sehingga mampu menyelaraskan pembangunan industri dengan kelestarian fungsi lingkungan hidup serta dapat memberi manfaat bagi masyarakat. Beberapa eksperimen awal dilakukan, utamanya untuk mengetahui dan memahami karakter sifat lembar limbah serta peluang perangkaian struktur bentuk dan visualisasinya. Implementasi persepsi gempal (Wong, 1989) yang menjadi dasar pemikiran dalam tahap pelaksanaannya. Beragam bahan pendukung bernilai green juga diujicoba-gunakan. Untuk menghasilkan panel dari bahan sampah kertas, kajian ini menggunakan metode konfigurasi silang vertikal menjadi pembentuk soliditas serta pencapaian nilai estetika pada permukaan panel yang dihasilkan. Secara keseluruhan proses perekatan menggunakan perekat termoplastis yakni polychloroprene.

Ide pemanfaatan sampah kertas juga bertujuan untuk membantu mengurangi polusi sampah kertas dan membersihkan lingkungan perkotaan. Kegiatan pengumpulan dan pemilahan sampah kertas ini diharapkan akan memberikan peluang kerja bagi masyarakat untuk meningkatkan taraf hidupnya serta membantu 
pemerintah daerah dalam menangani pengelolaannya. Permasalahan dalam penelitian ini adalah, kemampuan metode konfigurasi silang vertikal dalam membentuk panel kertas (paperboard) yang rigid, kokoh, dan kuat serta kemampuannya dalam membentuk struktur produk-produk fungsional estetik yang akan dibuat.

Maksud dan tujuan yang diharapkan dapat dicapai dari kajian ini, antara lain:

1. Mengetahui kemampuan panel kertas (paperboard) yang dihasilkan dari sampah sebagai material perancangan interior yang bersifat eco-design, layak, dan dapat dipertanggungjawabkan, baik secara fungsi (panel, furniture, base, dan lain-lain) maupun estetis

2. Menentukan visualisasi permukaan panel yang sesuai dengan fungsinya sebagai material perancangan interior yang terarah dan bersifat global

3. Mendukung program reboisasi tanaman jenis pepohonan di hutan sebagai sumber bahan kayu untuk meningkatkan kualitas dan kuantitas produksinya.

\section{METODE PENELITIAN}

Kajian ini menggunakan metode eksperimen aplikatif sebagai upaya mengakomodasi pemahaman terhadap bahan dasar yang rapuh dan lemas sehingga dapat dioptimalkan menjadi produk panel yang kuat dan kokoh. Kajian ini juga mengaplikasikan pola konfigurasi silang vertikal dalam membangun struktur untuk mendapatkan konstruksi panel yang layak dan dapat dipertanggungjawabkan. Panel yang dihasilkan nantinya mempunyai kekuatan dan kesolidan, serta mampu membangun produk-produk fungsional yang bernilai estetis.

\section{PEMBAHASAN}

\section{Sampah Kertas}

Sampah kertas banyak didapatkan dari beberapa area, seperti: perkantoran, usaha fotokopi, sekolah, pertokoan, pinggir jalanan, dan lain-lain. Contohnya: 


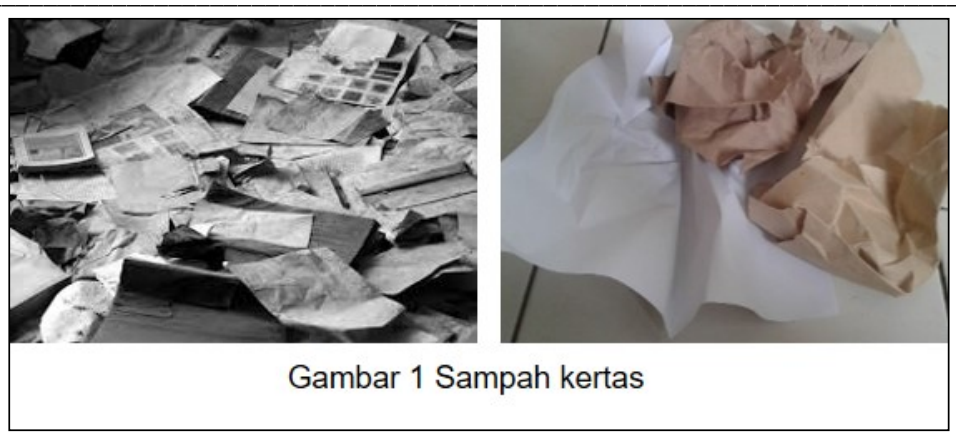

Alasan pemilihan sampah kertas berdasarkan pada beberapa pertimbangan, antara lain: jumlah banyak (yang berarti supply terjamin), mudah ditemukan, berbentuk lembaran, karakter material kuat, selama ini pemanfaatannya sebagai recycled paper, meningkatkan nilai tambah sampah kertas, penanggulangan sampah anorganik yang sustainable. Sebelumnya, penanganan sampah kertas dilakukan dengan meleburnya menjadi bubur kertas untuk kemudian didaur ulang menjadi menjadi recycle paper.

Berdasarkan data PD Kebersihan Kota Bandung pada tahun 2016, sampah di Kota Bandung mencapai 1.500 - 1.600 ton/hari oleh 2,4 juta penduduk, baru 250-ton yang diolah, sebagian besar blm diolah (Kompas.com, Minggu 21/8/2016). Komposisi sampah terdiri atas $60 \%$ sampah organik dan $40 \%$ sampah anorganik (Metrotvnews.com, Selasa 9/2/2016). Terkait dengan volume sampah kertas (yang termasuk sampah anorganik), maka dapat diketahui kalkulasi: sampah kertas $10 \%$ $(1300 \times 40 \%) \times 10 \%=52$ ton/hari. Berdasarkan kalkulasi tersebut dapat diketahui bahwa volume sampah kertas di Kota Bandung mencapai 52 ton/hari.

\section{Proses}

Eksperimen dilakukan melalui kegiatan produksi panel dari sampah daun kering dan kertas dengan metode konfigurasi silang vertikal yang dilanjutkan dengan aplikasi uji coba laboratorium untuk mengetahui kemampuan fisiknya. Data hasil uji coba tersebut digunakan sebagai acuan pengembangan produk panel sebagai benda fungsi sehari-hari. Eksperimen proses produksi meliputi beberapa tahapan, antara lain: 
a. Persiapan: pembuatan rencana produksi, pengumpulan bahan baku, pengumpulan bahan pendukung, dan penyiapan peralatan pendukung.

b. Proses pembuatan: penyiapan bahan baku utama (pembersihan dan perapian bahan baku sesuai modul) dan implementasi metode konfigurasi silang vertikal.

Secara spesifik, konfigurasi silang vertikal dideskripsikan sebagai metode pemanfaatan kemampuan posisi bahan yang vertikal dari susunan bahan lembaran yang rapuh, tipis, dan lemas menjadi struktur papan yang kuat, kokoh, dan solid. Secara struktural, konfigurasi silang vertikal terdiri dari empat lapis, antara lain:

- Dua lapis struktur dalam: merupakan dua layer masing-masing terbuat dari lembaran sampah yang sudah dipotong dan disusun secara vertikal. Penyusunan layer didukung oleh perekat polychloroprene. Kedua layer yang dihasilkan kemudian dikomposisikan secara bersilang dan direkatkan.

- Dua lapis permukaan: layer terluar dari panel yang menutup kedua sisi struktur dalam telah direkatkan. Kedua layer terluar tersebut terbuat dari sampah lembaran. Penyusunan layer terluar ini dilakukan secara horizontal. Perekatannya menggunakan perekat polychloroprene.

Keunggulan dari struktur ini antara lain kekuatan panel yang sangat memadai, kaku, dan mudah dilakukan perawatan. Sedangkan kelemahannya adalah proses pembuatannya sangat lama apabila dilakukan secara manual serta membutuhkan kemampuan yang akurat dan presisi pada proses pembuatannya.

c. Pasca produksi: uji coba kemampuan tekan dan lentur panel yang dilakukan di laboratorium. Pengujian dilakukan dengan menggunakan peralatan mekanis dengan pengukuran yang disesuaikan dengan standar uji ASTM (American Society for Testing and Material).

d. Hasil uji dimanfaatkan sebagai acuan standarisasi untuk pembuatan produk lanjutannya yang bernilai fungsi dan estetis sehingga menjadi produk yang layak pakai dan dapat dipertanggungjawabkan.

Selain kegiatan eksperimen, pengumpulan data juga dilakukan melalui kegiatan pengamatan lapangan, wawancara, dan kajian pustaka untuk mengobservasi 
aplikasi teknologi material terkait deskripsi dan jenis sampah kota, karakter limbah kota, teori bentuk dasar, nilai-nilai ramah lingkungan, bahan-bahan pendukung, aplikasi ragam konfigurasi bentuk, standar kemampuan material perancangan interior, proses produksi panel dari sampah daun kering dan kertas, serta perumusan masalah

\section{Paperboard}

Dari kegiatan eksperimen, implementasi metode konfigurasi silang vertikal berhasil mewujudkan produk panel dari bahan sampah kertas yang dinamakan paperboard. Rangkaian kertas yang terbentuk berasal dari jenis kertas HVS, karton, dan folio. Sementara lem perekat tetap menggunakan jenis polychloroprene. Proses pembuatannya sebagai berikut:

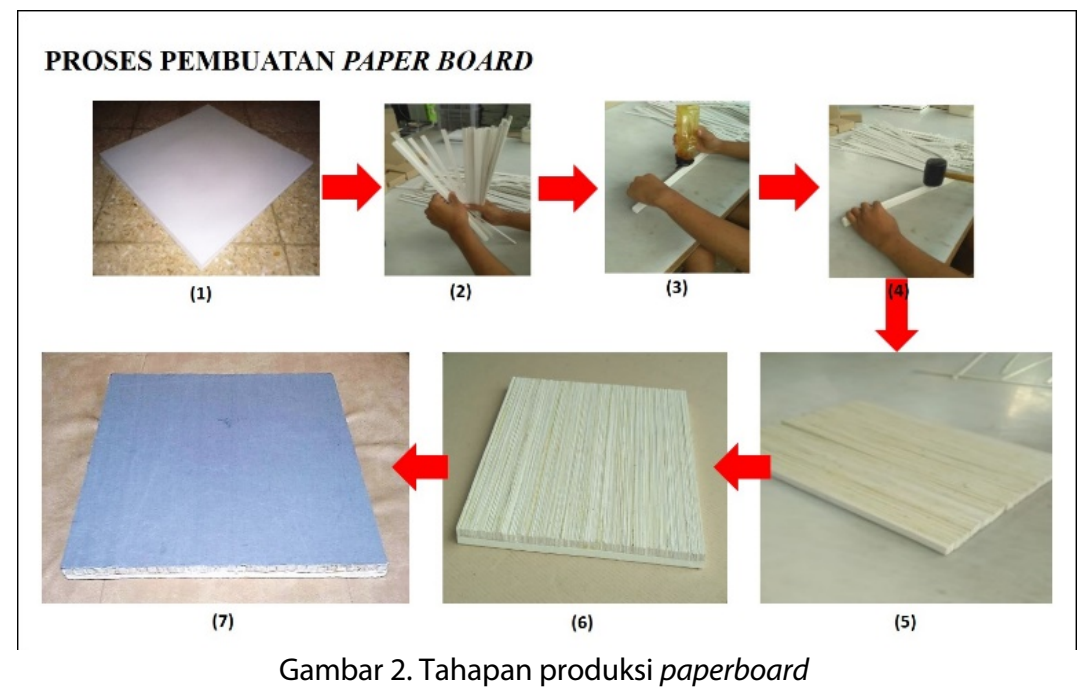

Tahapan-tahapan yang harus dilakukan merupakan usaha menyusun lembaran sampah kertas sehingga menjadi panel yang dapat dimanfaatkan sesuai ide perancangannya. Beberapa panel mempunyai penampilan fisik sebagai berikut : 


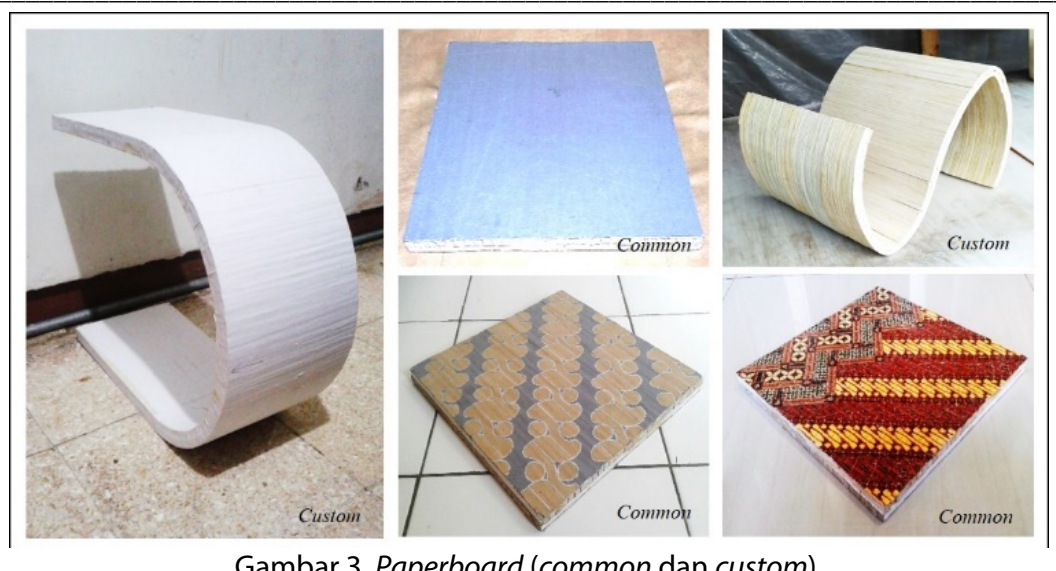

Gambar 3. Paperboard (common dan custom)

Paperboard mempunyai ketebalan $20 \mathrm{~mm}$. Karakter smooth dan fabric yang dihasilkan oleh paperboard memberikan peluang untuk lebih berperan dalam mewujudkan karakter elegan dalam perencanaan interior ruang. Paperboard mempunyai dua jenis panel, yaitu common dan custom. Kualifikasinya antara lain :

- Common: paperboard berbentuk bidang datar sama seperti panel dari kayu yang sudah ada sebelumnya. Proses produksinya bersifat reguler.

- Custom: paperboard yang berbentuk sesuai dengan permintaan pemberi order. Proses produksinya bersifat customize.

\section{Uji Fisik}

Pelaksanaan uji laboratorium paperboard dilakukan di Labortorium Rekayasa Struktur-ITB dengan kualifikasi uji tekan dan uji lengkung. Standarisasi uji sesuai dengan ASTM (American Society for Testing and Material). Pengujian kemampuan paperboard yang telah dilakukan memberikan hasil sebagai berikut:

Paperboard dengan dimensi lebar 30,9 mm dan tinggi 19,9 mm dengan panjang tumpuan $150 \mathrm{~mm}$ mempunyai kemampuan menahan beban sebesar maksimal 1,954 ton, sedangkan kekuatan lenturnya sebesar $40,44 \mathrm{~kg} / \mathrm{mm}^{2}$.

\section{Aplikasi}

Beberapa produk fungsi yang dihasilkan dari aplikasi paperboard antara lain: furnitur, elemen dekoratif, ornamen interior, struktur interior, dan sebagainya. Pemanfaatannya sebagai ornamen estetis, ornamen struktur, dan fungsional. Berikut dua jenis aplikasi paperboard pada produksi furnitur: 


\section{Meja tamu}

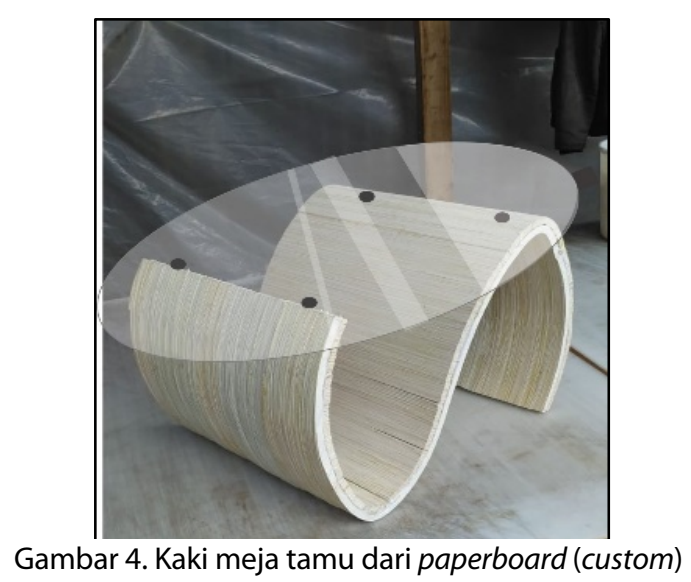

Keterangan:

Kaki meja tamu di atas mempunyai spesifikasi detail sebagai berikut:

Panjang $50 \mathrm{~cm}$, lebar $30 \mathrm{~cm}$, tinggi $35 \mathrm{~cm}$, ketebalan paperboard $20 \mathrm{~mm}$, jenis kertas bebas, (asal sampah kertas dari usaha fotokopi, percetakan, dan penerbitan), perekat polychloroprene, proses produksi manual, durasi pembuatan lima minggu.

2. Sarana meja dan mini storage

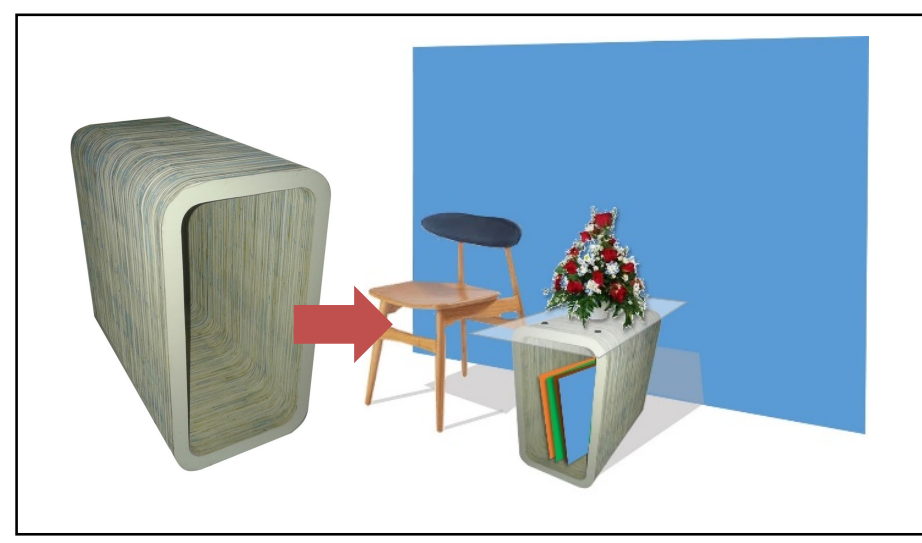

Gambar 5. Sarana meja dan mini storage

Keterangan:

Kaki sarana duduk di atas mempunyai spesifikasi detail sebagai berikut:

Panjang $51 \mathrm{~cm}$, lebar $20 \mathrm{~cm}$, tinggi $38 \mathrm{~cm}$, ketebalan paperboard $21 \mathrm{~mm}$, jenis kertas HVS dan karton (sampah kertas dari usaha fotokopi dan percetakan), perekat polychloroprene, proses produksi manual, durasi pembuatan tiga minggu. 


\section{PENUTUP}

Dari pembahasan di atas, dapat disimpulkan beberapa variabel antara lain:

- Sampah kertas dapat dimanfaatkan sebagai bahan baku pembuatan material struktur.

- Proses produksi membutuhkan waktu yang lama apabila dikerjakan secara manual. Pemanfaatan peralatan machinery sangat direkomendasikan.

- Implementasi konfigurasi silang vertikal mampu mengembangkan pemanfaatan lembaran sampah kertas yang tipis dan useless menjadi struktur paperboard yang kuat, rigid, dan bertekstur estetis.

- Dari kajian dan tes laboratorium di atas dapat diketahui bahwa paperboard mempunyai kemampuan fisik yang layak dan dapat dipertanggungjawabkan sebagai bahan baku produksi elemen interior fungsional dan estetis seperti: furnitur, decorative, dan pendukungnya.

- Membuka peluang pengembangan industri kreatif yang baru.

- Membuka lapangan kerja baru bagi masyarakat.

\section{DAFTAR PUSTAKA}

Acuan dari buku:

Asby, Mike dan Johnson, Kara. (2009). Material and Design. USA: Elsevier.

Sachari, Agus. (1989). Estetika Terapan. Bandung: Penerbit NOVA.

T. Dick, George. (1971). Aesthetic, An Introduction. New York: Pegasus Books.

Wong, Wucius. (1989). Beberapa Asas Merancang Trimatra (Terjemahan Adjat Sakri). Bandung: Penerbit ITB.

Acuan artikel dari jurnal:

Gultom, Lastri Anita. Dirhamsyah, Setyawati, Dina. (2013). Sifat Fisik Mekanik Papan Partikel Jerami Padi (Mechanical and physical properties of particle board rice straw), Jurnal Hutan Lestari, Universitas Tanjungpura. Vol. 1, No. 3, hal. 458 - 465, p-ISSN 23383127. Pontianak. Indonesia.

Hawari, Firman. (2012). Studi Faktor Kenyamanan Pada Kursi Santai Dengan Struktur Dari Material Dry Leaf Board. Penelitian PNPB - ITS, Surabaya.

Mulana, Farid. Hisbullah, Iskandar. (2011). Pembuatan Papan Komposit Dari Plastik Daur Ulang dan Serbuk Kayu serta Jerami Sebagai Filler, Jurnal Rekayasa Kimia 
dan Lingkungan. Jurusan Teknik Kimia FakultasTeknik, Vol. 8, No. 1, hal. 17 22, ISSN 1412-5064. Universitas Syiah Kuala Banda Aceh, Indonesia.

Qorina, Ummi. Mahyudin, Alimin. Handani, Sri. (2016). Pengaruh Persentase Massa Gipsum Dan Serat Terhadap Kuat Tekan Dan Kuat Lentur Papan Semen - Gipsum Berserat Eceng Gondok, jurnal Fisika. Universitas Andalas. Vol. 5, No. 3, Juli 2016, ISSN 2302-8491, Universitas Andalas, Padang, Indonesia.

Tarkono, Ali Hadi. (2016). Pemanfaatan Limbah Kelapa Sawit Sebagai Material Teknik, Jurnal Rotor, Teknik Mesin, Fakultas Teknik, Universitas Jember, Vol. 9 No. 2, hal. 94 - 99, ISSN 2460-0385, Jember, Indonesia. 